\title{
Subnational Elections and the Degree of Multipartism in Parliamentary Elections: \\ Evidence from the Canadian Case
}

MyoungHo Park*

(Dongguk University)

\section{Contents}

I. Introduction

II. Theoretical Considerations

III. Degree of Electoral Multipartism at

National and Subnational Levels in

Comparative Perspective
IV. Determinants of Riding-Level Electoral Multipartism in Legislative Elections

V. Concluding Remarks

- Keywords: Electoral Systems, Multipartism, Federalism, Canada.

\section{【 ABSTRACT 】}

Acknowledging the importance of diverse political institutions in explaining party system fragmentation, it attempts to extend the existing perspective on local elections to legislative elections under a single member simple plurality electoral system in federalsit context. It specifically assesses the importance of electoral competition patterns in local elections to determine electoral multipartism in a given district in legislative elections. Thus, the unit of analysis is the electoral district in which a legislative election under an SMSP is basically held. With evidence from the Canadian case, it argues that local/district partisan characteristics -different levels of partisan strength and subsequent partisan fragmentation-influence the degree of electoral multipartism in legislative elections across districts, while all other district-level factors are held constant. The findings suggest we need to consider sub-national and sub- provincial local elections for systematic understanding of electoral multipartism in legislative elections. 


\section{I . Introduction}

Existing scholarship suggests that it is important to explain why some polities have more fragmented electoral (or legislative) party systems than others and what factors work to determine the level of electoral partisan fragmentation. One line of research in the "Institutionalist" approach to party system development takes into account the variety of political institutions in the broader context of a political system, in order to understand the level of electoral partisan fragmentation in legislative elections. As such, most studies focus on the importance of presidential elections.1)

However, relatively little attention has been paid to the importance of sub-national elections for explaining the degree of multipartism across districts in legislative elections. Legislative elections in most cases (especially under the Single Member Simple Plurality electoral system) are basically held at the local electoral district level across a country. If there is any influence of electoral competition patterns in important national and sub-national local elections on the degree of electoral multipartism in legislative elections within a broader institutional context, then it is important to focus on the legislative electoral district in which legislative elections are held. Furthermore, federal systems allow for sub-national political/social diversity and the presence of political powers at multiple levels. They then influence the level of electoral partisan fragmentation in legislative elections actoss a country. Thus, sub-national elections become consequential in determining the degree of electoral multipartism across provinces for national legislative seats.

In this sense, Canadian case presents an interesting case insofar as it has adopted the SMSP electoral system to elect members to its national legislature and has a long history of federalism. Furthermore, it has been suggested that Canadian provinces often feature strikingly different national and provincial party systems. Thus, incorporation of the Canadian case contributes to our understanding of electoral and party systems from a comparative perspective.

With a preliminary analysis of party system developments at both national and sub-national levels in the Canadian case, then, it proceeds to the analysis of the determinants of the degree of electoral partisan fragmentation at the district level with an emphasis on the local/district partisan characteristics, while controlling for other district-level confounding factors.

1) Coppedge, M. Presidential Runoffs Do Not Fragment Legislative Party Systems. Paper presented at the 2000 American Political Science Association Annual meeting, Washington, D. C.2000., Cox, G. Making Votes Count. Cambridge University Press. 1997., Lijphart, A. . Electoral Systems and Party Systems: A Study of Twenty-Seven Democracies, 1945-1990. Oxford University Press. 1994., Shugart M. \& Carey J. Presidents and Assemblies: Constitutional Design and Electoral Dynamics. Cambridge University Press, 1992. 


\section{П. Theoretical Considerations}

The basic premise concerning the diversity of political institutions is that national legislative institutions do not exist in "institutional isolation within their political systems." National legislative members are elected either to form a national executive (in the context of parliamentary systems), or to co-exist with a national executive (in the context of presidential systems). As Shugart and Carey2 contend,2) isolation of assembly from the process of executive formation may distort our understanding of the number of parties [in legislative elections].

Researchers have examined the impact of presidential elections on the level of electoral partisan fragmentation in national legislative elections.3) Discussions of the influence of presidential elections on legislative elections are based on "coattail effects" of presidential candidates, which refer to "the ability of a candidate at the top of the ticket to carry into office-his partys candidates on the same ticket"4). It has been generally assumed that coattail effects emanate from the more important elections (like presidential elections) to the less important political offices (national legislature and local offices). The main argument for the importance of presidential elections is that electoral systems for electing the president and members of the legislature play a critical role in determining the shape of the electoral party system, political agenda, and prospects for cooperation and conflict between presidents and national legislatures.

As suggested, current studies on the effects of presidential elections on legislative electoral multipartism have been conducted at the national level. However, in most cases, legislative elections are held at the local electoral districts across a country, and the electoral partisan competition patterns appear to be different from district to district, contributing differently to the formation of a national-level party system. Thus, "any analysis of legislative elections must either be conducted at the district level or else make several assumptions regarding the distribution of the vote and influence of electoral laws in aggregate at the national level."5) That is, understanding the political consequences of electoral systems (and social heterogeneity as well) in national legislative elections can profit from district-level analyses.

Although much research has focused on presidential elections, only a few, if any, try to put an emphasis on the importance of sub-national local elections.6) Incorporating

2) Shugart \& Carey, (1992)

3) Shugart M. \& Carey J.(1992) Coppedge M, (2000); Cox G, (1997); Jones M (1995); Lijphart A 1994, Mainwaring S and Shugart M, (1997); Shugart M, (1995)

4) Beck, P. Party Politics in America. NY: Longman. 1997.

5) Jones, M. Electoral Institutions, Ethnic and Ideological Cleavages, and Candidate Competition in Presidential Elections. Paper presented at the annual Western Political Science Association Meeting. 2001.

6) Jones, M. . Federalism and the Number of Parties in Argentine Congressional Elections.Journal of Politics 59 (2): 538-549.1997, Samuels D. The Gubernatorial Coattail Effects: Federalism and 
presidential elections to explain legislative elections involves focusing on the effects of patterns of national-level electoral competition on the legislative electoral party systems across a polity. In contrast, taking into account local elections puts an emphasis on patterns of local-level electoral competition and their impact on legislative electoral party system fragmentation. Electoral competition for legislative seats in a given local district is subject not only to the usual institutional or national level influences at work, but also by local forces such as electoral competition patterns for prominent sub-national governmental offices.7)

The logic behind the importance of local elections in understanding electoral multipartism across districts in legislative elections is that given a certain type of institutional structure (federalism in this case) and social/political diversity following regional lines across a polity, there may coexist different types of sub-national party systems. This suggests that local (or district) partisan characteristics are presumably different from those of the national level. In addition, local districts differ from one another in terms of their partisan characteristics. Legislative elections are basically local district-level electoral competition" for legislative seats. In this sense, "local (or district)-level partisan fragmentation patterns" present in prominent local elections become relevant in explaining "local (or district)-level electoral partisan competition" in legislative elections.

Specifically, it is likely that the multiple levels of electoral competition for political offices in a federalist context influence each other. Furthermore, the subsequent presence of political powers at multiple levels across a country may lead to "the possibility of different party systems coexisting in given sub-national units." "8) Therefore, federalism may reflect "social diversity of the sort that can support separate parties," and encourage "party elites to maintain smaller regional parties rather than fuse with others" influencing the patterns of district-level electoral competition in national legislative elections across a country. In this sense, it becomes necessary for us to incorporate the local or district-level electoral partisan fragmentation for legislative seats because there are local parties operating geographically, and thus different types of party systems following regional lines in Canada.9)

Congressional Elections in Brazil. Journal of Politics 62 (1)2000a: 240-253. Samuels D. Concurrent elections, discordant results Presidentialism, Federalism, and Governance in Brazil.

Comparative Politics 33 (1)2000b: 1-20.

7) Kernell, S. \& Jacobson, G. . Strategy and Choice in Congressional Elections. New Haven: Yale University Press. 1981

8) Gaines, B. . Duvergers Law and the Meaning of Canadian Exceptionalism. Comparative Political Studies 32 (7): p.859. 1999.

9) Rae, D. . The Political Consequences of Electoral Laws. New Haven: Yale University Press. 1971, Riker, W. . Duvergers Law Revisited. In Bernard Grofman and Arend Lijphart (Eds.), Electoral Laws and Their Political Consequences. Agathon Press, Inc., pp. 19-42. 1986. 


\section{Degree of Electoral Multipartism at National and Subnational Levels in Comparative Perspective}

〈Table 1 $>$ Division of Seats and Vote Shares at the National Level in Canada

\begin{tabular}{|c|c|c|c|c|}
\hline \multirow{2}{*}{ Elections/Parties } & \multicolumn{2}{|c|}{1997 Election } & \multicolumn{2}{|c|}{2000 Election } \\
\hline & Seats & Votes & Seats & Votes \\
\hline Bloc Quebecois & 44 & $10.7 \%$ & 38 & $10.7 \%$ \\
\hline $\begin{array}{l}\text { Reform Party/ } \\
\text { Canadian Alliance }\end{array}$ & 60 & $19.4 \%$ & 66 & $25.5 \%$ \\
\hline Liberals & 155 & $38.5 \%$ & 172 & $40.8 \%$ \\
\hline New Democratic Party & 21 & $11.0 \%$ & 13 & $8.5 \%$ \\
\hline Progressive Conservative & 20 & $18.8 \%$ & 12 & $12.2 \%$ \\
\hline Total & 300 & $98.4 \%$ & 301 & $97.7 \%$ \\
\hline
\end{tabular}

Note: * the Canadian Alliance was Reform Party in 1997; the total number of seats is 301 for both elections.

Sources: Canadian Elections Studies, Various Years.

The Canadian case has been considered to be an exception to the conventional understanding of the relationship between electoral and party system development ${ }^{10}$ ) Contrary to traditional, institutionalist expectations, the degree of electoral multipartism at the national level has resulted in a multiparty instead of a two-party system. The effective numbers of electoral parties at the national level are 4.09 for the 1997 election and 3.77 for the 2000 election, following the Laakso-Taagepara Index $\left(\mathrm{N}=\left(\sum p_{i}{ }^{2}\right)^{-1}\right.$, where $p$ is the proportion of popular votes for party (or candidate) $i$ ).

〈Table 2 > Comparison of Electoral Multipartism at National and Riding Levels

\begin{tabular}{|c|c|c|c|}
\hline \multicolumn{2}{|c|}{1997 Election } & \multicolumn{2}{|c|}{2000 Election } \\
\hline National & Riding & National & Riding \\
\hline 4.09 & 2.90 & 3.77 & 2.68 \\
\hline
\end{tabular}

Note: Riding is the Canadian term used for district or constituency; The riding level degree of electoral multipartism is an average of all the local ridings following the formula: $D_{N}$ $=\left(\sum N_{i}\right) / d$ (When $N$ is the.effective number of parties at district $i, d$ is the total number of local ridings)

Table 1 shows the division of seats and vote shares in recent parliamentary elections at the national level in Canada, indicating that there have been five major parties involved.

10) Gaines (1999); Palfrey (1989); Taagepara and Shugart(1985, 1989) 
These five parties occupy all the legislative seats and more than $95 \%$ of vote shares at the national level. These two elections are no exception of Canadian norms. The average effective number of electoral parties at the national level in Canada from 1935 to 1993 was 3.1 (Gaines 1999)11), suggesting that there have been more than three parties in the Canadian national political landscape for some time.

However, one finds a different picture when we introduce the average degree of electoral competition across ridings, as shown in Table 2 above. The average levels of electoral partisan fragmentation at the riding level in the 1997 and 2000 elections are relatively closer to two-party electoral competitions across ridings than those at the national level. These two elections are also no exception to Canadian political history. The average degree of electoral competition at the riding levels in Canada has been relatively closer to two-party systems. Therefore, it appears safe to say that the institutional argument also works in the Canadian case at the riding, although not the national level.(2.54 from 1935 to 1999)

The simultaneous comparison of the degree of electoral partisan fragmentation at national and riding levels clearly shows that the appropriate unit of analysis is the local ridings, in order to better understand the degree of electoral competition in the Canadian legislative elections under SMSP electoral systems. The level of electoral competition at the riding level is clearly different from that of the national level. While a relatively multiparty system emerges at the national level, the degree of electoral competition at the riding level seems to be relatively closer to a two-party competition.

As suggested above, the shape of party systems at the national level is an aggregation of local-level party systems. ${ }^{12}$ ) In this sense, the relative two party electoral competitions across ridings in Canada appear to lead to multiparty systems at the national level. Also, the patterns of electoral partisan competition for legislative seats across local ridings, differs from riding to riding, and, subsequently, province to province (as an aggregation of ridings), contributing in a variety of ways to the formation of the party system at the national level.

The degrees of electoral multipartism of some ridings, or a region, are higher than that of the riding average, and relatively closer to that of the national level. In these cases, one sees multiparty electoral competition (high electoral competition). The levels of electoral partisan fragmentation in other ridings or regions, on the other hand, are lower than that of the national-level, and closer to the average competition at the riding level. We can see relative two party electoral competitions in those ridings (low electoral competition). Thus, when we focus on the degree of electoral competition at sub-national levels, we find more dynamics in the levels of electoral multipartism across a nation Cox.13)

A clue emerges here for understanding the "Canadian exception" in terms of electoral

11) Gaines (1999)

12) Chhibber, P. \& Kollman, K. Party Aggregation and the Number of Parties in India and the United States. American Political Science Review 92 (2): 329-342.1998.

13) $\operatorname{Cox}(1997)$. 
and party system developments. As mentioned earlier, the interaction between federalism and party system development have generated a wide range of important questions for comparative political research. Numerous research questions have been raised concerning the impact that a federalist polity structure has in providing multiple arenas for electoral competitions for political offices within a given country.

Since there are a variety of institutional contexts and electoral systems where electoral partisan competition occurs, the possibility arises of differing patterns or degrees of electoral competition in the various constituent elements of the federation. The Canadian federalist system has historically seen local provincial governments maintain or increase their autonomy in many areas of public policy. ${ }^{14)}$

In this sense, such scholars as Palfrey, Taagepara, and Grofman have maintained that Canada has bipartisan provincial politics, while it is a kind of multiparty system at the national level. Palfrey15) represents the conventional view concerning the Canadian exception by arguing that "The most well-known exception is Canada, where provincial party systems are bipartisan, but not all provinces have the same two dominant parties. This produces a patchwork national party system that is a conglomeration of strong regional parties."

〈Table 3 > Provincial-Level Comparison of Electoral Multipartism In Canadian Legislative Elections

\begin{tabular}{|c|c|c|c|}
\hline Province & 1997 Election & 2000 Election & Average $1935-93^{*}$ \\
\hline Alberta & 2.63 & 2.43 & 3.1 \\
\hline British Columbia & 3.26 & 2.95 & 3.4 \\
\hline Manitoba & 3.26 & 3.80 & 3.1 \\
\hline New Brunswick & 3.85 & 3.28 & 2.4 \\
\hline New Found Land & 3.55 & 2.94 & 2.2 \\
\hline Northwest Territories & 3.05 & 3.12 & $* *$ \\
\hline Nova Scotia & 3.61 & 3.51 & 2.4 \\
\hline Nunavut & & 1.93 & $\star *$ \\
\hline Ontario & 3.04 & 2.87 & 2.7 \\
\hline Prince Edward Island & 2.70 & 2.64 & 2.1 \\
\hline Quebec & 3.05 & 2.76 & 2.7 \\
\hline Saskatchewan & 3.42 & 2.93 & 3.0 \\
\hline Yukon & 4.44 & 3.45 & ** \\
\hline
\end{tabular}

Note: * provided by Gaines (1999); ** Not included in Gaines analysis. The provincial-level degree of electoral competition is based on parties vote share at the province level.

Sources: Canadian Election Studies, Various Years.

14) Sharman C. Parties and Federalism in Australia and Canada. Australian National University Press, 1994.

15) Palfrey, T.(1989) 
Taagepara and Grofman ${ }^{16)}$ agree with Palfrey, saying that Canada, which might appear another exception, with three major parties, has at the local level two-party politics - the parties are simply not always the same two throughout the country Furthermore, Rae $^{17)}$ identifies a possibility of regional parties surviving locally and contributing to a national-level multiparty system. He indicates that: "Intense hostility between overlapping regional, cultural, and linguistic groups produced a strong basis of support for locally strong minority parties"

Therefore, with different (mostly) two parties competing, Canadian provinces have two party electoral competitions, producing multipartism at the national level. The very reason why Canada has a multiparty system at the national level is the provincial- level two party competitions for legislative seats with alternating regional combinations of the two competing parties. Conventional arguments simply do not stand up to empirical scrutiny. For example, Gaines argue that "This claim about Canadian federal elections, as a "stylized fact," emphasizes the adjective at the expense of the nounit is scarcely a fact at all."18) With the national legislative elections from 1935 to 1993 in Canada, the degree of electoral competition, using the data on 'provincial-level election returns', clearly indicate that provincial-level electoral multipartism is consistently above 2 and almost always above 3. With exactly two parties in an electoral competition, the degree of electoral partisan fragmentation cannot exceed 2. However: "There are only 9 cases out of 177 (roughly $5 \%$ ) of a province having an $N$ of 2 or less".

The elections of 1997 and 2000 were no exception to the trend of multiparty electoral competition at the province level in Canada. The average degree of electoral competition at the provincial level for the 1997 election was 3.35 and 2.97 for the 2000 election. This suggests that more than two parties competed at the provincial level for seats in Canada's national legislature.

We can find dynamic electoral competition across provinces as shown in Table 3. Some provinces show relatively higher degrees of electoral partisan fragmentation than the riding average, closer to national-level multipartism. A relatively lower level of electoral multipartism emerges than with the national-level party system and closer to the riding-level average in electoral competition in some provinces.

The provincial-level degree of electoral multipartism is an aggregation of riding- level electoral competition across a province. A riding is a basic unit of electoral competition from which a national-level party system is formed under the SMSP electoral system. Canadian ridings have historically had more than two parties competing for legislative seats. According to Gaines ${ }^{19)}$, "Most of these elections do not seem to fit the generalization

16) Taagepara R. \& Grofman B. Rethinking Duvergers Law: Predicting the Effective Number of Parties in Plurality and RP Systems-Parties minus Issues Equals One. European Journal of Political Research 13 (4)1985: 342

17) Rae, D.(1971), p.94

18) Gaines B (1999) p.842

19) Gaines B (1999) pp.843 855 
that Canada has bipartisan electoral districts". Specifically, at the riding level where "the bite of single member simple plurality electoral systems is felt," the degree of electoral competition spans the two-to-four-party continuum and, furthermore, it hasn't changed over time until 1993.

$\langle$ Table 4 > Riding-Level Comparison of Electoral Multipartism in Canadian Legislative Elections

\begin{tabular}{lcc}
\hline \multicolumn{1}{c}{ Province } & 1997 Election & 2000 Election \\
\hline Alberta & $2.54(26)$ & $2.31(26)$ \\
British Columbia & $3.06(34)$ & $2.78(34)$ \\
Manitoba & $3.24(14)$ & $3.05(14)$ \\
New Brunswick & $3.01(10)$ & $2.85(10)$ \\
New Found Land & $2.42(7)$ & $2.55(7)$ \\
Northwest Territories & $3.43(2)$ & $3.12(1)$ \\
Nova Scotia & $3.36(11)$ & $3.14(11)$ \\
Nunavut & $*$ & $1.93(1)$ \\
Ontario & $2.88(103)$ & $2.72(103)$ \\
Prince Edward Island & $2.61(4)$ & $2.59(4)$ \\
Quebec & $2.75(75)$ & $2.55(75)$ \\
Saskatchewan & $3.25(14)$ & $2.74(14)$ \\
Yukon & $4.48(1)$ & $3.45(1)$ \\
National Average & $2.90(301)$ & $2.68(301)$ \\
\hline
\end{tabular}

Note: * the province of Nunavut was included in the Northwest Territories in the 1997 election; 0 are the number of ridings allocated in the province; The riding-level degree of electoral competition is an average degree of electoral multipartism at the riding level in each province using formula: $D p=\left(\sum N_{i}\right) / d$ (When $N$ is the effective number of parties at district $i, d$ is the total number of local ridings in a province)

Table 4 shows the average degree of electoral competition at the riding level across a province. The table clearly indicates the dynamics of electoral partisan fragmentation at the riding level. The ridings of some provinces experience relatively multiparty types of electoral competition like that of the national level, while relatively two-party competition also emerges as reflected in the national riding average. There are around three or four parties competing with each other for legislative seats in some provinces. At the same time, two or three major parties emerge in other provinces. There are 10 out of 25 provinces where the degree of electoral competition is closer to the national riding average, but quite distant from the national-level partisan fragmentation. The remaining 15 provincial cases are closer to the national level party system and distant from that of the national riding average.

We find evidence here that is contrary to conventional wisdom. Canadian party systems 
have not been two-party competitions at the provincial level throughout history. There have also been more than two parties competing 'at the riding level' in Canadian parliamentary elections. Divergent degrees of electoral competition across ridings and provinces following regional lines have emerged. Some ridings and provinces are relatively closer to two-party systems (national riding average) whereas others are closer to the national-level degree of electoral competition (multiparty systems). Thus, the national-level party system in Canada is an aggregation (or mixture) of local-level (riding and provincial) electoral partisan fragmentations.

Furthermore, when one reviews electoral returns at the riding and provincial levels, it seems that there have been different combinations of parties competing at the provincial level, indicating that there have 'existed regionally strong but nationally weak parties' in Canada. There have been a variety of political parties in Canada. But, the liberals (Liberal Party of Canada) and conservatives (Progressive Conservative Party of Canada) are the only two ever to have formed the national government. Overall, Canadian parties in Canada have been strong in certain regions and weak in others .

$\langle$ Table 5 $\rangle$ Regional Bases of Canadian Parties (Seats)

\begin{tabular}{cccccc}
\hline Parties & Atlantic (32) & Western* (88) $^{*}$ Ontario (103) & Quebec (75) & $\begin{array}{c}\text { Partys } \\
\text { Total Seats }\end{array}$ \\
\hline BQ & - & - & - & 38 & 38 \\
CA & - & 64 & 2 & - & 66 \\
Liberal & 19 & 14 & 100 & 36 & 169 \\
NDP & 4 & 8 & 1 & - & 13 \\
PC & 9 & 2 & - & 1 & \\
\hline
\end{tabular}

Note: * Provinces of Alberta, British Columbia, Manitoba and Saskatchewan

〈Table 6> Regional Bases of Canadian Parties (Vote Shares)

\begin{tabular}{ccccc}
\hline Parties & Atlantic & Westem & Ontario & Quebec \\
\hline \hline BQ & - & - & - & 39.9 \\
CA & - & $49.9 \%$ & $23.6 \%$ & - \\
Liberal & $40.7 \%$ & $25.3 \%$ & $51.5 \%$ & $44.2 \%$ \\
NDP & $16.6 \%$ & $12.3 \%$ & $14.4 \%$ & - \\
PC & $31.3 \%$ & $9.9 \%$ & - & $5.6 \%$ \\
\hline
\end{tabular}

Sources: Canadian Election Studies, Various Years

First-past-the-post electoral systems generally reward the winning party and penalize the second and especially third place parties. Yet, the same electoral systems can work to a third party's advantage, if the party's political support is regionally (orgeographically) concentrated. Pluralistic electoral systems can also over representregional parties. This is 
true in the Korean as well as the Canadian case. 3 The CA (Canadian Reform Conservative Alliance) has thrived in the west, the base of 64 out of a total of 66 seats (50\% of vote shares) in the 2000 general elections.

Table 5 and 6 show the division of seats and vote shares across Canada. While the $\mathrm{CA}$ is dominant in the Western provinces, it competes with the Liberals and the NDP for legislative seats in the region. Even though the CA is not on the ballot in Atlantic Canada, it is the main contender with the NDP against the Liberals in the province of Ontario. There emerge three major parties competing in Atlantic Canada (Liberals, Conservatives and NDP). The province of Quebec has two major parties competingBloc Quebecois and Liberals. The BQ is the classical regional party whose seats are totally from one province, yet is the third largest party in the Canadian House of Commons.

It appears to be clear, therefore, why we should focus on riding-level electoral competition in Canadian legislative elections. The party system at the national level shows a mixed picture since it includes different local (ridings and regions) electoral partisan fragmentation across the country. Furthermore, the combination of parties competing for legislative seats changes from province to province in Canada. Thus, a relative two party system in some ridings (provinces), where a certain party (or two parties) has relatively strong electoral support, blends with a multiparty system in other ridings (provinces), where three or four major parties are competing. Recent Canadian parliamentary elections saw different levels of partisan strength and, subsequently, different degrees of electoral competition along regional lines.

\section{Determinants of Riding-Level Electoral Multipartism in Legislative Elections}

\section{Data and Method}

Under a federalist institutional context political powers exist at multiple levels and political/social diversity emerges along regional lines. As shown in the preliminary analysis section of the chapter, different patterns of electoral partisan fragmentations follow regional lines in Canada, and, therefore, it is highly likely that the local/riding partisan characteristics affect the degree of electoral competition when electing the members of the Canadian House of Commons across local ridings.

The dependent variable is the effective number of electoral parties at the riding level in the 2000 general elections, based on the Laakso-Taagepara Index. The primary independent variable under review is the local/riding partisan characteristics. The variable is reflected in different levels of partisan strength and electoral partisan fragmentation in a given riding. It is measured through the degree of electoral partisan fragmentation at the riding level in provincial legislative elections.

Canadians elect provincial legislative members so that the majority party of the 
provincial legislative body forms the provincial local government. While Koreans elect their governor directly, Canadians elect their provincial prime minister (governor) through provincial legislative members. Provincial elections are used to measure the local/riding partisan characteristics in a given riding following the same formula used for the dependent variable. The most recent provincial elections for the 2000 legislative election are used for the local/riding partisan characteristics.

$\langle$ Table 7〉 Provincial Elections in Canada

\begin{tabular}{lccc}
\hline \multicolumn{1}{c}{ Province } & Year of Provincial Election & Electoral Division & Riding (301) \\
\hline \hline Alberta & 1997 & 83 & 26 \\
British & 1996 & 75 & 34 \\
Columbia & 1999 & 57 & 14 \\
Manitoba & 1999 & 55 & 10 \\
New Brunswick & 1999 & 48 & 7 \\
Newfoundland & 1999 & 19 & 1 \\
Northwest Territories & 1999 & 52 & 11 \\
Nova Scotia & 1999 & 19 & 1 \\
Nunavut & 1999 & 103 & 103 \\
Ontario & 1996 & 27 & 4 \\
Prince Edward Island & 1998 & 124 & 75 \\
Quebec & 1999 & 58 & 14 \\
Saskatchewan & 2000 & 17 & 1 \\
Yukon & & & \\
\hline
\end{tabular}

Table 7 summarizes the information about provincial legislative elections in Canada. The electoral returns for electoral divisions in provincial elections in a province are aggregated to match each riding allocation in the province. With the exception of the province of Ontario, each riding consists of several electoral divisions across a province. Therefore, the electoral returns of electoral divisions in each riding are aggregated following partisan affiliations in each riding in accordance with the local/riding partisan characteristics.

Since the presence of control variables improves the fit of the model, this analysis introduces control variables. First, the presence (or absence) of incumbent legislative members running for re-election in a given riding controls for the impact of a candidate running for re-election on the level of electoral competition in the riding. Ridings where incumbents ran were coded zero while open seats were coded one. The absence of incumbents is expected to exert an increasing effect on the level of electoral competition across ridings. 
While the Korean case provides measures for challenger candidate quality and the nature of districts, the Canadian case supplies more in-depth information about the nature of ridings, called "district diversity." Students of congressional elections have offered theoretical reasons to expect heterogeneous districts to be more competitive than homogeneous districts. District diversity -the mix of social demographic characteristics in a given congressional district- is a central trait that underlies the degree of electoral competition for legislative seats in elections to the U.S. House.

There are clear theoretical reasons to believe that district diversity should have discernible ramifications for electoral politics. Certain types of social, economic, and demographic characteristics are positively (or negatively) related to support for parties of the left or right. The set of traits associated with one or another political party seems to have implications for the distribution of political opinion within a district. In turn, the level of district diversity will influence the degree of electoral partisan fragmentation in the district

Bond ${ }^{20)}$ however, using the same measure for district diversity, found no significant relationship between constituency diversity and electoral competition for House elections in the 1970' On the other hand, Hermson and Gimpel found evidence that district diversity did have electoral consequences, but only in Democratic House primaries. Therefore, empirical research so far has failed to find systematic evidence that the population diversity of congressional districts has a direct impact on the level of electoral competition in U.S. congressional elections. Given these unexpected empirical findings, there have been a variety of efforts like Koetzle and Bond and his colleagues to revise district diversity.

The typical measure for riding diversity is the Sullivan index. Sullivan Sullivan ${ }^{21)}$ offered a straightforward index of district diversity, which allows for the inclusion of key social demographic characteristics. The index is an expression of the probability of the average proportion of unshared characteristics between any two members of a population. Therefore, the closer to one the index, the more diverse the district is. The diversity index developed and used in this chapter is based on five variables that are considered to tap ethnic, educational, generational and economic dimensions of district characteristics (Table 8 below summarizes the variables used for the index in this study). The formula for constructing a district diversity index is:

$$
A w=1-\left\{\Sigma Y^{2} / V\right\}
$$

Where:

$\mathrm{A}_{\mathrm{w}}=$ the index of diversity within a population

$\mathrm{Y}^{2}=$ the proportion of the population within a given category of each variable used in the index

$\sum 1$ through $\mathrm{P}$, where $\mathrm{P}$ is the total number of categories within all variables

20) Bond, J(1983)

21) J. Political Correlates of Social, Economic and Religious Diversity in the American States.

Journal of Politics 35 (February 1973): 70-84. 
$\mathrm{V}=$ the number of variables used in the index

〈Table 8> Construction of Riding Diversity Index

\begin{tabular}{ll}
\hline \multicolumn{1}{c}{ Variables } & \multicolumn{1}{c}{ Categories } \\
\hline Age & Seniors (Older Than 65); Non Seniors \\
Education & College Education; Less than College Education \\
Home Ownership & Home Owner; Rent \\
Employment & Employed; Not Employed \\
Language & English; French; Other Languages \\
\hline
\end{tabular}

Note: All the statistics used for the construction of riding diversity index are based on the 1996 Canadian Census data.

The control variables should have a positive influence on the degree of electoral competition across ridings in the 2000 election. Accordingly, the level of electoral competition at the riding level is expressed in the following equation:

$$
Y=\Theta F(P, D, D)
$$

Where $\mathrm{Y}$ is the effective number of electoral parties in a given riding in the 2000 election, $P$ is the local/riding partisan characteristics, $\mathrm{D}$ is the riding diversity combining the variables of age, education, home ownership, employment and language. I is whether there is an incumbent(s) and $\theta$ is a stochastic factor. Function $F$ is assumed to be linear and the above function can be transformed into a regression line as follows:

$$
\mathrm{Y}=B_{1}+B_{2} \mathrm{X}_{1}+B_{3} \mathrm{X}_{2}+B 4 \mathrm{X}_{3}+B_{5} \mathrm{X}_{4}+\mathrm{u}
$$

in which $B$ 's are unknown but fixed parameters, $X$ 's 1 through 4 represent chosen independent variables (local/riding partisan characteristics, riding diversity and open seat/or not) and $\mathrm{u}$ represents the stochastic factor, $\Theta$.

1) Analysis and Discussion

$\langle$ Table 9> Local Partisan Characteristics and Legislative Electoral Multipartism Across Ridings in the 2000 Canadian Elections

\begin{tabular}{lcc}
\hline \multicolumn{1}{c}{ Variables } & Unstandarized Coefficients & Robust Standard Error \\
\hline \hline Riding Diversity &. .629 & .415 \\
Open Seat or Not & $143^{\star}$ & .087 \\
Local Partisan Characteristics & $.180^{\star \star}$ & .074 \\
Constant & $2.552^{\star \star \star}$ & .236 \\
\hline
\end{tabular}

Note: $\mathrm{R} 2=.039, \mathrm{~N}=299 ;{ }^{*}$ Significant $<.10, * \star$ Significant $<.05, * \star *$ Significant $<.001$. 
Table 9 shows how local partisan characteristics influence the level of electoral competition across ridings in the 2000 Canadian parliamentary elections, while controlling for potentially confounding factors at the riding level. It also shows the relevancy of the local partisan characteristics from sub-national elections for understanding the degree of electoral competition at the riding level in the Canadian case. The level of electoral competition from the closest provincial election in a given riding is significantly influential in deciding the effective number of electoral parties in the riding in the legislative election. Given the basic unit of electoral competition in legislative election under the SMSP electoral system, it appears to be the case that the local/riding district partisan characteristics decide the degree of electoral competition across ridings in legislative elections.

Where the degree of local partisan characteristics is relatively high (more parties in the last local elections) in a given riding, for example, the degree of electoral competition in the riding tends to be higher (more parties) in the following legislative election. In contrast, a riding in which the level of electoral partisan fragmentation is relatively low (fewer parties), tends to have fewer effective electoral parties in the subsequent legislative election. The estimated regression coefficient for the variable is significant at the .05 level for a two- tailed $t$ test. The estimated coefficient of .180 indicates that, in an average riding, an increase in riding partisan characteristics from 1 to 2 would result in an increase of approximately .180 of an effective number of electoral parties at the riding level, other factors remaining constant.

As mentioned earlier, previous empirical research of U.S. congressional elections has failed to find systematic evidence that the population diversity of a congressional district has a direct influence on the level of electoral competition.22) The sign on the regression coefficient is not in the predicted direction, and the models that have been developed have little explanatory power.23)

One can also find the same pattern from the Canadian case. The variable of riding diversity is not statistically significant either, and the relationship runs in the opposite direction from what was expected. The estimated coefficient indicates that the more diverse ridings are likely to have a lower degree of electoral competition.

However, the presence of an incumbent(s) running for re-election is statistically significant at the level of $90 \%$ for a two-tailed $t$ test and indicates that the absence of incumbent candidates in a given riding tends to increase the level of electoral partisan fragmentation in the riding. For instance, a legislative contest without incumbents in a given riding results in a .143 increase in the effective number of electoral parties in the riding.

22) Bond, J.(1983), Bond, J., Campbell, K., \& Cottrill, J. "The Puzzle of Constituency Diversity Revisited: Conditional Effects of District Diversity on Competition in Congressional Elections." Paper presented at the Southern Political Science Association annual meeting. 2001.

23) "Correlates of Social, Economic and Religious Diversity in the American States." Journal of Politics 35 (February 1973): 70-84. 
As Koreas mayoral elections are held at the same district boundary as the district for legislative elections, this provides a good monitor of district-level partisan characteristics; the elections of provincial legislative members in Ontario are held at the same riding boundary as the federal parliamentary elections. Therefore, this could be said to reflect the riding-level dynamics of electoral competition or partisan fragmentation in influencing legislative elections in a given riding.

$\langle$ Table 10〉 Riding Partisan Characteristics and Legislative Electoral Multipartism Across Districts in the 2000 Canadian Elections (Ontario Only)

\begin{tabular}{lcc}
\hline Variables & Unstandarized Coefficients & Robust Standard Error \\
\hline \hline Riding Diversity & $-3.572^{\star \star *}$ & .604 \\
Open Seat or Not & .159 & .260 \\
Riding Partisan Characteristics & $334^{\star \star}$ & .117 \\
Constant & $3.203^{\star \star \star}$ & .394 \\
\hline
\end{tabular}

Note: $\mathrm{R} 2=.282, \mathrm{~N}=103 ;$ * Significant $<.10$, ** Significant $<.05, * * *$ Significant $<.001$.

The variable of riding partisan characteristics is statistically important, indicating that a riding with relatively high level of electoral partisan fragmentation in local elections tends to have a higher level of electoral competition in legislative elections, while controlling for other factors. Specifically, the change from 1 to 2 in the effective number of electoral parties across ridings in local elections results in a .334 increase in the level of electoral multipartism in a legislative election.

While the presence of incumbent legislators has no impact on the degree of electoral competition, riding population diversity becomes statistically significant for both models. Table 10 introduces two different dependent variables to measure the same concept-the degree of electoral competition at the riding level. They are the effective number of electoral parties and the electoral margin between the vote shares of the top two finishers. Even though riding diversity is statistically important at $99 \%$ for both models, they are different in terms of substantive implications.

Our main concern is riding partisan characteristics. While controlling for other confounding factors, the variable of riding partisan characteristics show statistical and substantive importance in explaining the degree of electoral competition in the form of electoral margins. This point indicates the robustness of the riding partisan characteristics in explaining the degree of electoral competition across ridings.

\section{Concluding Remarks}

The major findings are as follows: First, this study confirms the necessity of 
sub-national and district-level analysis of the degree of electoral partisan competition in legislative elections, especially under the SMSP electoral systems. We found that the party system at the national level is an aggregation of the dynamics of electoral partisan fragmentation across districts and localities within a country. In other words, the party system at the national level of a polity is a product of electoral partisan fragmentations across the local district. The national-level party system, therefore, can be seen as a "patchwork" of localized (or regionalized) party systems in both countries, because a variety of types of electoral partisan characteristics follow regional lines. As a result of the concentration of electoral support along provincial lines in the Canadian case, we found different combinations of parties competing within sub-national units.

Furthermore, we found that the very reason Canada has a relative multiparty system at the national level is the provincial-level two-party competitions for legislative seats with alternating regional combinations of the competing parties. Given the multiparty electoral competition across provinces, the major competing parties vary following regional lines. Specifically, some Canadian provinces show relatively higher degree of electoral partisan fragmentation than the riding average (relative two party systems), approaching the national-level of multipartism. In contrast, other provinces display relatively lower levels of electoral competition than the national-level party system and are closer to the riding-level average. Research on the degree of electoral multipartism in legislative elections would be enhanced if greater consideration were given to the potential impact of sub-national and sub-provincial elections on the level of multipartism across electoral districts in legislative elections. 


\section{References}

Arseneau, T. Federalism and 'New' Parties of the Right in Alberta: From the Progressive to Reform In Parties and Federalism in Australia and Canada. Ed. Campbell Sharman. Australian National University. 1994.

Beck, P. Party Politics in America. NY: Longman. 1997.

Bond, J. The Influence of Constituency Diversity on Electoral Competition in Voting for Congress, 1974-197. Legislative Studies Quarterly 8 (May): 201-217,1983

Bond, J., Campbell, K., \& Cottrill, J. The Puzzle of Constituency Diversity Revisited: Conditional Effects of District Diversity on Competition in Congressional Elections. Paper presented at the Southern Political Science Association annual meeting. 2001.

Blais, A \& Carty, K. The Psychological Impact of Electoral Laws: Measuring Duverger's Elusive Factor. British Journal of Political Science 21 (1): 79-83.1991.

Chhibber, P. \& Kollman, K. Party Aggregation and the Number of Parties in India and the United States. American Political Science Review 92 (2): 329-342.1998.

Coppedge, M. Presidential Runoffs Do Not Fragment Legislative Party Systems. Paper presented at the 2000 American Political Science Association Annual meeting, Washington, D. C.2000.

Cox, G. Making Votes Count. Cambridge University Press.1997.

Gaines, B. Duverger's Law and the Meaning of Canadian Exceptionalism. Comparative Political Studies 32 (7): 835-961. 1999.

Jones, M. Electoral Laws and the Survival of Presidential Democracies. Notre Dame: University of Notre Dame Press. 1995.

Jones, M. Federalism and the Number of Parties in Argentine Congressional Elections. Journal of Politics 59 (2): 538-549.1997.

Jones, M. Electoral Institutions, Ethnic and Ideological Cleavages, and Candidate Competition in Presidential Elections. Paper presented at the annual Western Political Science Association Meeting. 2001.

Kernell, S. \& Jacobson, G. Strategy and Choice in Congressional Elections. New Haven: Yale University Press. 1981.

Sullivan, J. "Political Correlates of Social, Economic and Religious Diversity in the American States." Journal of Politics 35 (February 1973): 70-84. Sullivan J. Political Correlates of Social, Economic and Religious Diversity in the American States. Journal of Politics 35 (February 1973): 70-84.

Lijphart, A. Electoral Systems and Party Systems: A Study of Twenty-Seven Democracies, 1945-1990. Oxford University Press. 1994.

Mainwaring, S. \& Shugart, M. Conclusion: Presidentialism and Party System. In Scott P. Mainwaring and Matthew S. Shugart (eds.). Presidentialism and Democracy in Latin America. Cambridge University Press. 1997.

Morley, T. Federalism and the New Democratic Party. in Parties and Federalism in 
Australia and Canada. Ed. Campbell Sharman. Australian National University. 1994 Palfrey, T. A Mathematical Proof of Duverger's Law. In Models of Strategic Choice in Politics. (Eds.), Peter Ordeshook Ann Arbor: University of chigan Press. 1989 Rae, D. The Political Consequences of Electoral Laws. New Haven: Yale University Press. 1971.

Riker, W. Duverger's Law Revisited. In Bernard Grofman and Arend Lijphart

(Eds.), Electoral Laws and Their Political Consequences. Agathon Press, Inc., pp. 19-42. 1986.

Samuels, D. "The Gubernatorial Coattail Effects: Federalism and Congressional Elections in Brazil." Journal of Politics 62 (1)2000a: 240-253.

Samuels, D. "Concurrent elections, discordant results" Presidentialism, Federalism, and Governance in Brazil. Comparative Politics 33 (1)2000b: 1-20.

Sharman, C. Parties and Federalism in Australia and Canada. Australian National University Press, 1994.

Shugart, M. \& Carey, J. Presidents and Assemblies: Constitutional Design and Electoral Dynamics. Cambridge University Press,1992.

Shugart, M. "The Electoral Cycle and Institutional Sources of Divided Presidential Government." American Political Science Review 89 (2)1995: 327-343.

Sullivan, J. Political Correlates of Social, Economic and Religious Diversity in the American States. Journal of Politics 35 (February 1973): 70-84.

Taagepara, R. \& Grofman, B. "Rethinking Duverger's Law: Predicting the Effective Number of Parties in Plurality and RwP Systems-Parties minus Issues Equals One. European Journal of Political Research 13 (4)1985: 341-352

Taagepera, R. \& Shugart, M. Seats and Votes: The Seats and Determinants of Electoral Systems. Yale University Press,1989. 